Intervention A portable ultrasound machine was purchased by Countess Mountbatten House Hospice at £5780. Suitable training was undertaken by the author at $£ 450$.

Results 50 scans were performed over one year:

2 at home: both no ascites [died at home within seven days]

17 in OPA: 8 admitted for paracentesis

9 no ascites [ 1 U.retention - catheter inserted ]

31 in IPU: 17 ascitic drains placed

9 no ascites

5 catheters inserted for U.retention

Outcomes

- 11 admissions avoided

- 31 transfers avoided [31x £600] $=£ 18600$

- 124 bed days saved [31x4 minimum wait for scan at $£ 294$ per day $]=£ 36456$

Patient experience improved:

- Unnecessary admission avoided

- Transfer avoided

- Faster relief of symptoms

- Reduced length of stay.

\section{P-143 DEVELOPMENT OF THE PORTABLE ULTRASOUND FACILITY AT COUNTESS MOUNTBATTEN HOUSE HOSPICE}

Anna Hume. Countess Mountbatten House, Southampton, UK

\subsection{6/bmjspcare-2018-hospiceabs. 168}

Background Facilitating preferred place of care and death (PPC/PPD) are important aspects of good palliative care. Disease progression, increasing frailty and reduced mobility are associated with increased incidence of thrombosis (DVT) and urinary retention causing distress and sometimes admission. The development of ascites is another indicator of general frailty $(50 \%$ died within 10 days of paracentesis) and the importance of short admission. The development of our portable ultrasound facility was envisaged as a useful tool to improve delivery of care and assist achievement of PPC/PPD.

Intervention Availability of the portable ultrasound machine to all Countess Mountbatten House teams to identify/exclude ascites, DVT, Urinary retention and to assist transfusion/hydration when cannulation is difficult.

Results 50 scans were performed over eight months:

4 at home: 4 no ascites (2 died at home within 9 days, 1 U.retention - catheter inserted, 1 cellulitis with indwelling drain - admitted)

19 in OPA: 8 ascites - admitted for paracentesis

7 no ascites [2 GB abscess, 1 U.retention]

2 DVT confirmed [anticoagulated at home]

2 DVT excluded

27 in IPU: 11 ascitic drains placed

7 no ascites [5 U.retention - catheter inserted]

5 DVT confirmed [anticoagulant started]

3 assisted cannulations for transfusion

1 pericardial effusion (transferred to cardiology).

\section{Outcomes}

- 14 admissions avoided

- 26 transfers for scan or central line avoided
- 4 units of blood not wasted

- 104 bed days saved [26 $\times 4$ days minimum wait for scan]

Patient experience improved:

- Unnecessary admission avoided

- Transfer avoided

- Faster relief of symptoms

- Reduced length of stay.

\section{P-144 PROGRESS AND DEVELOPMENT FOLLOWING AN AUDIT OF ROUTINE WEIGHING ON A HOSPICE INPATIENT UNIT}

Jan Codling, Amanda Connors, Imerjit Manak, Jennie Pickard, Alison Phippen, Samantha Kay, David Waterman. St Ann's Hospice, Greater Manchester, UK

\subsection{6/bmjspcare-2018-hospiceabs.169}

Background A previous audit highlighted that an absence of weighing patients on admission potentially limited ability to meet best practice standards for medicine management and nutritional assessment. A survey also highlighted a staff misconception that patients do not like being weighed. Clinical staff now receive training demonstrating the inaccuracy of estimating body weight and routine weighing was introduced for inpatients and daycare patients.

Aim To measure compliance to weighing daycare patients. To maintain the change in practice of weighing patients by providing regular feedback, promoting clinical ownership and responding to staff views on how to improve the process.

Method Inpatients: A monthly audit is conducted by non-registered nurses who are often the person who is tasked with weighing patients on the ward. The audit measures if the patient's weight was recorded on their medicine chart within three days of admission.

Daycare: An audit measuring if patients were weighed within two visits and easily accessible on the patient's electronic record was conducted by a medical student six months after routine weighing was introduced for daycare patients. Results

Abstract P-144 Table 1 Results of the Inpatient Weighing Audit

\begin{tabular}{lcc}
\hline Inpatients & $\begin{array}{c}\text { Weight recorded on medicine } \\
\text { chart }\end{array}$ & $\begin{array}{c}\text { Weighed within } 3 \text { days of } \\
\text { admission }\end{array}$ \\
\hline $\begin{array}{l}\text { October } \\
2017\end{array}$ & $62 \%$ & $61 \%$ \\
March 2018 & $89 \%$ & $75 \%$ \\
\hline
\end{tabular}

Abstract P-144 Table 2 Results of the Day Care Weighing Audit

\begin{tabular}{lcccc}
\hline Daycare & $\begin{array}{c}\text { Patients } \\
\text { weighed }\end{array}$ & $\begin{array}{c}\text { Weighed } \\
\text { within 2 visits }\end{array}$ & $\begin{array}{c}\text { Weight recorded on } \\
\text { electronic record }\end{array}$ & $\begin{array}{c}\text { Weight accessible } \\
\text { via read code }\end{array}$ \\
\hline $\begin{array}{l}\text { May } \\
2018\end{array}$ & $95 \%$ & $77 \%$ & $77 \%$ & $74 \%$
\end{tabular}

Conclusions Both audits demonstrated improvements in compliance to weighing patients. During the inpatient audit, it became apparent that some patients have a long hospice stay and need to be re-weighed a minimum of monthly. 